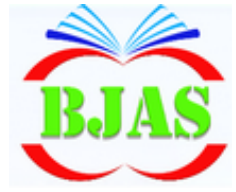

ISSN 1814 - 5868
Available online at http://bjas.bajas.edu.iq

https://doi.org/10.37077/25200860.2021.34.1.15

College of Agriculture, University of Basrah

Basrah J. Agric. Sci. 34(1): 171-179, 2021
Basrah Journal

of Agricultural

Sciences

E-ISSN: 2520-0860

\title{
The Effect of Alcoholic Extract of Rhizomes of Greater Galangal (Alpinia galanga L.) on the Serum Antioxidant Enzymes for Japanese Quail During Oxidative Stress Induced by Hydrogen Peroxide
}

\author{
Asrar M. S. Al-Mosawy \& Khalid C. K. Al-Salhie* \\ Department of Animal Production, College of Agriculture, University of Basrah, Iraq \\ *Corresponding author: Knnz1977@ yahoo.com \\ Received 20 May 2020; Accepted 2 August 2020; Available online 23 February 2021
}

\begin{abstract}
This study aimed to investigate the effect of alcoholic extract of greater galangal rhizomes on the serum antioxidant enzymes level in Japanese quail during oxidative stress induced by hydrogen peroxide. Two hundred and sixteen, 7 days-old of Japanese quail birds were randomly distributed into four groups $(n=54)$ with three replicates per group and 18 chicks per replicate. The groups as follows: the first group was drank water without any addition as control. The second group was supplied with $4 \mathrm{ml}^{-1}$ hydrogen peroxide $\mathrm{H} 2 \mathrm{O} 2$ (40\%). The third group was supplied with $4 \mathrm{ml}^{-1}$ both hydrogen peroxide (40\%) and alcoholic extract of greater galangal rhizomes. The fourth group was supplied with $4 \mathrm{ml}^{-1}$ alcoholic extract of greater galangal rhizomes. The results showed the lowest significant $(\mathrm{P}<0.05)$ decrease of malonaldehyde (MDA), aspartate aminotransferase (AST) and alanine aminotransferase (ALT) concentrations in the fourth group while, the highest significant $(\mathrm{P}<0.05)$ increase was recorded in the second group. The highest significant $(\mathrm{P}<0.05)$ activity level of superoxide dismutase (SOD) and glutathione peroxidase $(\mathrm{GPx})$ recorded in the fourth group, on the other hand, it was significantly lowest in the second group. The results explained there is no significant difference $(\mathrm{P}<0.05)$ in the concentration of MDA,SOD, GPx AST and ALT between the first (control) and third groups. The results indicated there is no significant differs between males and females in the MDA,SOD, GPx AST and ALT. It can be concluded, oxidative stress was caused a negative impacts on serum SOD, GPx. AST and ALT enzymes. Moreover, it was caused an increase in MDA levels. The alcoholic extract of rhizomes of greater galangal was reduced and reversed the $\mathrm{H} 2 \mathrm{O} 2$ impacts. All parameters non-significantly influenced by sexes.
\end{abstract}

Keywords: Greater galangal, Oxidative stress, Antioxidant enzymes, Quail.

\section{Introduction}

Poultry industry is associated with a wide variety of environmental, technological, nutritional and physiological, internal stress factors responsible for reduced productive and reproductive productivity and compromised health (Surai \& Fisinin, 2016 a, b). A recent information shows clearly that the overproduction of free radicals is very often damaged by antioxidant defences. Integrated antioxidant defence systems have been developed in poultry during evolution. These protection systems control the formation of free 


\section{Al-Mosawy \& Al-Salhie / Basrah J. Agric. Sci., 34(1): 171-179, 2021}

radicals and maintain redox balance. Indeed, the redox balance in the cell whole body has been shown to be responsible for regulating the range of different physiological and biochemical processes, including cell signalling, gene expression and homeostasis maintenance (Chen et al ., 2014; Corsello et al., 2018). Oxidative damage to oxygen free radicals, such as it is understood that superoxide anions are one of the factors participations in processes for illnesses such as cancer (Halliwell \& Gutteridge, 1989). Biological specimens consist of a variety of reactive substances of thiobarbituric acid excluding lipid hydroperoxides and aldehydes increase due to oxidative stress. Formation of the lipid hydroperoxides caused by oxidative lipid damage disorder of attached membrane receptors. Most of those by malonaldehyde (MDA) is the product of lipid peroxidation. Oxygen-free radicals are formed by aerobics metabolism and are most frequently replaced by endogenous antioxidants such as superoxide dismutase (SOD) and Glutathione peroxidase (GPx) (Das, 2002).

Endogenously antioxidants such as vitamins and $\beta$-carotene, avoid oxidative reactions from occurring in the cascade combining with the free radicals (Diplock, 1994). Natural antioxidants from herbs have attracted considerable interest due to their safety and potential nutritional, physiological and productive impacts (Sultan et al, 2019; 2020).

Several plant products have been studied as a powerful source of antioxidants. Herbal antioxidants include vitamins; phenolic, compounds including flavonoids and phenols and volatile compounds (Carrubba \& Calabrese, 1998). Galangal contains is rich in antioxidants. The use of Galangal in feeding leads to the expulsion of toxins and inhibiting free radicals (Mahae \& Chaiseri, 2009). Galangal rhizomes are one of its most important components, as it contains many bioactive compounds such as essential fatty acids and minerals (iron, phosphorus, manganese and zinc). Also, it contains vitamin $\mathrm{A}, \mathrm{C}$, and B complex, as well as, alkaloids, phenols and proteins (Jirovetz et al, 2003).

Galangal rhizome has a wide variety of traditional applications medicine (Yang \& Eilerman, 1999). Abdel-Azeem \& Basyony (2019) indicated that broiler feeding on an experimental diet with galangal rhizomes by $(250,500$ and $750 \mathrm{mg})$ for six weeks, obtained an increase in the level of antioxidant enzymes e.g. Glutathione peroxidase (GPx), superoxide dismutase (SOD) and catalase, and improved growth efficiency, antioxidant biomarkers, raw protein and ether extract in breast meat, and reduced broiler mortality. In addition, galangal rhizomes extract has a strong antioxidant potential, a mixture of polyphenol compounds with good antioxidant properties which can be used in heat stress for broilers. Negm \& Ragheb, (2019) indicated that rats feeding on an experimental diet in addition to dried galangal led to an increase in the levels of Glutathione peroxidase and a decrease in the malonaldehyde.

This study aimed to investigate the effect of alcoholic extract of rhizomes of greater galangal on the serum antioxidants status for Japanese quail subjected to oxidative stress induced by hydrogen peroxide.

\section{Material \& Methods}

This study was carried out from 9 September 2019 to 23 October 2019 at quail farm, College of Agriculture, University of Basrah. Two hundred and sixteen, seven days-old of 


\section{Al-Mosawy \& Al-Salhie / Basrah J. Agric. Sci., 34(1): 171-179, 2021}

Japanese quail (Coturnix japonica) Temmink \& Schlegel, 1849 were randomly distributed into four groups $(n=54)$ with three replicates per group and 18 chicks per replicate. The groups as follows: the first group was drank water without any addition as control. The second group was supplied with $4 \mathrm{ml}^{-1}$ hydrogen peroxide $\mathrm{H}_{2} \mathrm{O}_{2}(40 \%)$. The third group was supplied with $4 \mathrm{ml}^{-1}$ both hydrogen peroxide (40\%) and alcoholic extract of greater galangal rhizomes. The fourth group was supplied with 4 $\mathrm{ml}^{-1}$ alcoholic extract of greater galangal rhizomes. The birds were fed two experimental diets. The starter diet was containing approximately $24 \%$ crude protein and 2900 $\mathrm{kcal} . \mathrm{kg}^{-1}$ metabolizable energy while, the grower diet was containing approximately $20 \%$ crude protein and $2900 \mathrm{kcal} . \mathrm{kg}^{-1}$ metabolizable energy (table 1) (NRC, 1994). The birds were given ad libitum access to food and water. The birds were housed in the same rearing methods. Dry rhizomes of greater galangal were obtained from a local market in the city of Basrah, Iraq.

Table (1): Ingredients and nutrient composition of bird's diet.

\begin{tabular}{|c|c|c|}
\hline Ingredient \% & First diet\% & Second diet\% \\
\hline Yellow corn & 39 & 40.5 \\
\hline Wheat & 17 & 24 \\
\hline Soybean meal (44\%) & 36 & 25 \\
\hline protein concentration & 4 & 4 \\
\hline Corn oil & 1 & 0.5 \\
\hline Limestone & - & 2 \\
\hline Dicalcium phosphate & - & 1 \\
\hline *Premix & 100 & 100 \\
\hline Total & Calculated composition \\
\hline \multicolumn{2}{|c|}{} \\
\hline Metabolizable energy (kcal.kg- & 2900 & 2900 \\
\hline 1) & 24 & 20.00 \\
\hline Crude protein (\%) & 3.90 & 3.93 \\
\hline Crude fat (\%) & 3.39 & 4.11 \\
\hline Crude fibre (\%) & 120.83 & 145 \\
\hline Calorie: protein ratio & 1.88 & 2.31 \\
\hline Calcium (\%) & 0.37 & 0.46 \\
\hline Phosphorus available (\%) & 0.30 & 0.38 \\
\hline Lysine (\%) & 1.72 & 1.06 \\
\hline Methionine (\%) & 0.93 & 0.83 \\
\hline Methionine + Cysteine (\%) &
\end{tabular}

${ }^{1}$ Protein concentrate used from Al-Hayat Company, Jordanian Origin, to provide the following per kg of diet: $44 \%$ protein, 2800 kcal.kg ${ }^{-1} \mathrm{ME}, 12 \%$ fat, $25 \%$ ash, 5\% calcium, 2.9\% phosphorus, $2.55 \%$ methionine + Cysteine, $2.8 \%$ lysine. $*$ Premix contents: vitamins in amounts per kg diet: vit. A: 2500 IU, vit.D3: 5000IU, vit.E: 75mg, vit. K: $3 \mathrm{mg}$, vit. B1: 3 mg, vit. B2: $8 \mathrm{mg}$, vit. B6: $5 \mathrm{mg}$, vit. B12: $0.016 \mathrm{mg}$, folic acid: $2 \mathrm{mg}$, biotin: $0.20 \mathrm{mg}$, pantothenic acid: $13 \mathrm{mg}$, Nicotinic acid :55 mg, Choline chloride 1600mg. Mineral composition (mg kg diet): Cooper :16 mg, Iodin:1.25mg, Iron:40mg, Manganese:120 mg, Selenium: 30mg, Zinc 100mg. 
The alcoholic extract of rhizomes of greater galangal was made according to (Harborne, 1984). The hydrogen peroxide $(40 \%)$ was obtained from Al-Brooj office for medical equipment in Basrah city.

\section{Blood collection and study parameters:}

At 45 days old of bird ( 3 males and 3 females) were slaughtered. Blood samples from the Jugular vein were obtained and centrifuged at 3000 RPM for 10 minutes to collect serum. The method of Malondialdehyde (MDA) reaction with Thiobarbituric acid was used to estimate the Malondialdehyde concentration. The reaction is carried out in an acidic field .The concentration of Malondialdehyde was calculated by using the spectrophotometer at a wavelength of $353 \mathrm{~nm}$ (Yagi, 1998). Superoxide dismutase (SOD) and glutathione peroxidase (GPx) were estimated according to (Sanja et al., 2015). Kits, manufactured by Biomerieux Company were used to estimate the activity of the aspartate aminotransferase (AST) and alanine aminotransferase (ALT) enzymes. Using a spectrophotometer at $505 \mathrm{~nm}$ wavelength and calculate the activity of enzymes by using a standard curve prepared for this purpose.

\section{Statistical analysis:}

A factorial experimental with a complete randomize design was used to analyze data. The first factor was nutritional groups and the second was gender (males and females). the data in this study were analyzed by ANOVA using SPSS ver. 21 (SPSS, 2016). Least significant difference (L.S.D.) was used to compare differences among the means. Triplicates were used and significant level in all experiments was 0.05 .

\section{Results \& Discussion}

The results presented in table 2 showed a significant $(P<0.05)$ decrease of MDA concentration in the fourth group compared to other groups. On the other hand, a significant increase $(\mathrm{P}<0.05)$ was recorded in the second group compared to all the studied groups. While there is no significant difference $(\mathrm{P}<0.05)$ in the concentration of MDA between the first (control) and third groups. The results showed the highest significant levels of SOD and GPx activity in the fourth, while the lowest significant activity was reported in the second group. Although there is no significant difference $(\mathrm{P}<0.05)$ between the first (control) and third group. The reason behind the increases in the MDA levels detected in the second group may be due to the autoxidation of plasma lipids (Wu et al., 2004). MDA, one of the main lipid peroxidation ingredients, has been extensively analyzed and calculated as a lipid peroxidation index (Schrader \& Fahimi, 2006). The highest significant activity levels of SOD and GPx concentration detected in the fourth group may be due to the galangal supplementation which considers a rich source of antioxidants that lead to the expulsion of toxins and inhibiting free radicals (Mahae \& Chaiseri 2009). Galangal rhizomes contain many bioactive compounds such as essential fatty acids and minerals (iron, phosphorus, manganese and zinc). Besides, it contains vitamin $\mathrm{A}, \mathrm{C}$, and $\mathrm{B}$ complex, as well as, alkaloids, phenols that enhance antioxidants status (Jirovetz et al, 2003). Abdel-Azeem \& Basyony (2019) indicated that broiler fed on an experimental diet with galangal rhizomes by 250, 500 and $750 \mathrm{mg}$ for six weeks, obtained an increase in the level of antioxidant enzymes (GPx, SOD) and catalase. These findings are in agreement with Negm .\& Ragheb (2019) who 


\section{Al-Mosawy \& Al-Salhie / Basrah J. Agric. Sci., 34(1): 171-179, 2021}

mentioned that rats fed on an experimental diet supplemented with dried galangal led to an increase in the levels of Glutathione peroxidase, on the other hand, led to a decrease in the malonaldehyde. The current results indicated no significant $(\mathrm{P}<0.05)$ differs between males and females in the MDA, SOD and GPx. This obtained results may be due to the extract of the galangal rhizomes contains antioxidants which inhibit free radicals, on the other hand lead to maintain a normal level of enzymes in males and females (Mahae \& Chaiseri, 2009).

Table (2): Effect of alcoholic extract of rhizomes of greater galangal on the serum MDA, SOD and GPx for Japanese quail during oxidative stress induced by hydrogen peroxide (Mean \pm SD).

\begin{tabular}{|c|c|c|c|c|c|c|}
\hline \multirow[t]{2}{*}{ Parameters } & \multirow[t]{2}{*}{ Gender } & \multicolumn{4}{|c|}{ Groups } & \multirow{2}{*}{ Mean } \\
\hline & & G1 & G2 & G3 & G4 & \\
\hline \multirow{6}{*}{$\begin{array}{c}\text { MDA } \\
\left(\text { Umol. }^{-1}\right)\end{array}$} & \multirow[t]{2}{*}{ Males } & $1.23^{\mathrm{A}}$ & $1.38^{\mathrm{A}}$ & $1.19^{\mathrm{A}}$ & $1.09^{\mathrm{A}}$ & $1.22^{\mathrm{A}}$ \\
\hline & & \pm 0.04 & \pm 0.04 & \pm 0.02 & \pm 0.01 & \pm 0.11 \\
\hline & \multirow[t]{2}{*}{ Females } & $1.20^{\mathrm{A}}$ & $1.35^{\mathrm{A}}$ & $1.18^{\mathrm{A}}$ & $1.04^{\mathrm{A}}$ & $1.19^{\mathrm{A}}$ \\
\hline & & \pm 0.05 & \pm 0.05 & \pm 0.04 & \pm 0.05 & \pm 0.12 \\
\hline & \multirow[t]{2}{*}{ Mean } & $1.21^{\mathrm{b}}$ & $1.37^{\mathrm{a}}$ & $1.18^{\mathrm{b}}$ & $1.07^{\mathrm{c}}$ & \multirow{2}{*}{$\begin{array}{c}\text { The interaction } \\
\text { groups } \times \text { gender } \\
\text { N.S }\end{array}$} \\
\hline & & \pm 0.04 & \pm 0.04 & \pm 0.03 & \pm 0.04 & \\
\hline \multirow{6}{*}{$\begin{array}{c}\text { SOD } \\
\left(\text { Umol. }^{-1}\right)\end{array}$} & \multirow[t]{2}{*}{ Males } & $2.02^{\mathrm{A}}$ & $1.07^{\mathrm{A}}$ & $1.97^{\mathrm{A}}$ & $2.46^{\mathrm{A}}$ & $1.88^{\mathrm{A}}$ \\
\hline & & \pm 0.13 & \pm 0.47 & \pm 0.17 & \pm 0.12 & \pm 0.57 \\
\hline & \multirow[t]{2}{*}{ Females } & $2.11^{\mathrm{A}}$ & $1.14^{\mathrm{A}}$ & $1.65^{\mathrm{A}}$ & $2.47^{\mathrm{A}}$ & $1.84^{\mathrm{A}}$ \\
\hline & & \pm 0.24 & \pm 0.57 & \pm 0.32 & \pm 0.05 & \pm 0.60 \\
\hline & \multirow[t]{2}{*}{ Mean } & $2.06^{\mathrm{b}}$ & $1.10^{\mathrm{c}}$ & $1.81^{\mathrm{b}}$ & $2.46^{\mathrm{a}}$ & \multirow{2}{*}{$\begin{array}{c}\text { The interaction } \\
\text { groups } \times \text { gender } \\
\text { N. S }\end{array}$} \\
\hline & & \pm 0.17 & \pm 0.47 & \pm 0.29 & \pm 0.08 & \\
\hline \multirow{6}{*}{$\begin{array}{c}\text { GPx } \\
\left(\text { Umol. }^{-1}\right)\end{array}$} & \multirow[t]{2}{*}{ Males } & $778.26^{\mathrm{A}}$ & $531.88^{\mathrm{A}}$ & $767.24^{\mathrm{A}}$ & $1012.19^{\mathrm{A}}$ & $772.39^{\mathrm{A}}$ \\
\hline & & \pm 9.06 & \pm 6.37 & \pm 13.31 & \pm 17.15 & \pm 177.72 \\
\hline & \multirow[t]{2}{*}{ Females } & $768.32^{\mathrm{A}}$ & $524.36^{\mathrm{A}}$ & $762.38^{\mathrm{A}}$ & $1006.18^{\mathrm{A}}$ & $765.31^{\mathrm{A}}$ \\
\hline & & \pm 5.77 & \pm 10.89 & \pm 10.15 & \pm 22.84 & \pm 178.34 \\
\hline & \multirow[t]{2}{*}{ Mean } & $773.29^{\mathrm{b}}$ & $528.12^{\mathrm{c}}$ & $764.81^{\mathrm{ab}}$ & $1009.18^{\mathrm{a}}$ & \multirow{2}{*}{$\begin{array}{c}\text { The interaction } \\
\text { groups } \times \text { gender } \\
\text { N. S }\end{array}$} \\
\hline & & \pm 8.70 & \pm 8.98 & \pm 10.92 & \pm 18.36 & \\
\hline
\end{tabular}

The different small letters in the same row show significant differences $(P<0.05)$.

The same capital letters in the same row show no significant differences $(P<0.05)$. 
The results of table (3) indicated that the lowest significant $(\mathrm{P}<0.05)$ activity levels of AST and ALT enzymes concentration recorded in the fourth group while the second group was the highest. There is no significant $(\mathrm{P}<0.05)$ differences between the first (control) and third groups. In the present study, the serum activity of liver markers, including AST and ALT, increased in the second group compared to other groups. These findings have shown that oxidative stress caused by hydrogen peroxide hepatic damage has been reported previously
(Chen et al., 2017). Some reports have shown that natural antioxidants may reduce activities of liver markers and enhancement of liver function (Mansouri et al., 2014; Khastar, 2015). Van Beek et al. (2013) indicated that AST and ALT enzymes are indicators of liver health, as high levels of them indicate that the liver has various diseases or oxidative stress. When the liver is infected, these enzymes will transfer to the serum as a result of tissue damage or destruction (Burke, 2002).

Table (3): Effect of alcoholic extract of rhizomes of greater galangal on the serum AST and ALT for Japanese quail during oxidative stress induced by hydrogen peroxide (Mean \pm SD)

\begin{tabular}{|c|c|c|c|c|c|c|}
\hline \multirow[t]{2}{*}{ Parameters } & \multirow[t]{2}{*}{ Gender } & \multicolumn{4}{|c|}{ Groups } & \multirow[t]{2}{*}{ Mean } \\
\hline & & G1 & G2 & G3 & G4 & \\
\hline \multirow{6}{*}{$\begin{array}{l}\text { AST } \\
\left(\text { IU.- }{ }^{-1}\right)\end{array}$} & Males & $28.94^{\mathrm{A}}$ & $34.37^{\mathrm{A}}$ & $28.74^{\mathrm{A}}$ & $24.40^{\mathrm{A}}$ & $29.11^{\mathrm{A}}$ \\
\hline & & \pm 1.45 & \pm 0.86 & \pm 1.57 & \pm 0.76 & \pm 3.83 \\
\hline & Females & $28.37^{\mathrm{A}}$ & $35.58^{\mathrm{A}}$ & $29.34^{\mathrm{A}}$ & $24.00^{\mathrm{A}}$ & $29.32^{\mathrm{A}}$ \\
\hline & & \pm 0.75 & \pm 1.05 & \pm 1.78 & \pm 1.11 & \pm 4.44 \\
\hline & Mean & $28.65^{\mathrm{b}}$ & $34.97^{\mathrm{a}}$ & $29.04^{b}$ & $24.20^{\mathrm{c}}$ & The interaction \\
\hline & & \pm 1.08 & \pm 1.08 & \pm 1.54 & \pm 0.88 & $\begin{array}{c}\text { groups } \times \text { gender } \\
\text { N. S }\end{array}$ \\
\hline \multirow{6}{*}{$\begin{array}{c}\text { ALT } \\
\left(\text { IU }^{-1}\right)\end{array}$} & Males & $23.94^{\mathrm{A}}$ & $31.37^{\mathrm{A}}$ & $24.74^{\mathrm{A}}$ & $20.40^{\mathrm{A}}$ & $25.11^{\mathrm{A}}$ \\
\hline & & \pm 1.45 & \pm 0.86 & \pm 1.57 & \pm 0.76 & \pm 4.26 \\
\hline & Females & $23.37^{\mathrm{A}}$ & $32.58^{\mathrm{A}}$ & $25.34^{\mathrm{A}}$ & $20.00^{\mathrm{A}}$ & $25.32^{\mathrm{A}}$ \\
\hline & & \pm 0.75 & \pm 1.05 & \pm 1.78 & \pm 1.11 & \pm 4.92 \\
\hline & Mean & $23.65^{\mathrm{b}}$ & $31.97^{\mathrm{a}}$ & $25.04^{\mathrm{b}}$ & $20.20^{c}$ & The interaction \\
\hline & & \pm 1.08 & \pm 1.08 & \pm 1.54 & \pm 0.88 & $\begin{array}{c}\text { groups } \times \text { gender } \\
\text { N.S }\end{array}$ \\
\hline
\end{tabular}

The different small letters in the same row show significant differences $(\mathrm{P}<0.05)$.

The same capital letters in the same row show no significant differences $(\mathrm{P}<0.05)$. 


\section{Al-Mosawy \& Al-Salhie / Basrah J. Agric. Sci., 34(1): 171-179, 2021}

The results showed there is no significant $(\mathrm{P}<0.05)$ differs among males and females in the AST and ALT levels. These findings may be due to the role of antioxidants in suppressing free radicals and controlling the level of liver enzymes in both males and females (Mahae \& Chaiseri, 2009). These obtained results are in agreement with Ayoola et al. (2015) who indicated no significant influenced by sexes in AST and ALT serum enzymes for Japanese quail birds.

\section{Conclusion}

In conclusion, oxidative stress was caused a negative impacts on serum SOD, GPx. AST and ALT enzymes. Moreover, it was caused an increase in MDA levels. The alcoholic extract of rhizomes of greater galangal was reduced and reversed the $\mathrm{H}_{2} \mathrm{O}_{2}$ impacts. All parameters non-significantly influenced by sexes.

\section{Acknowledgements}

The authors are very much grateful to the staff of quail farm at College of Agriculture, the University of Basrah for their supports of this study.

\section{Conflict to interest}

There is no conflict of interest.

ORCID: Khalid Ch. K. Al-Salhie

https://orcid.org/0000-0003-1121-7056

\section{References:}

Abdel-Azeem, A. A. S., \& Basyony, M. M. (2019). Some blood biochemical, antioxidant biomarkers, lipid peroxidation, productive performance and carcass traits of broiler chicks supplemented with Alpinia galangal rhizomes extract during heat stress. Egyptian Poultry Science Journal, 39, 345-363.

Ayoola, A. A., Egbeyale, L. T., Sogunle, O. M., Ekunseitan, D. A., \& Adeyemi, A. A. (2015). Effects of age and sex on haematological and serum biochemistry in Japanese quails. Bulletin of Animal Health and Production in Africa, 63, 4351.https://www.ajol.info/index.php/bahpa/article/vie w/131795

Burke, M. D. (2002). Liver function: test selection and interpretation of results. Clinics in Laboratory Medicine, 22, 377-390. https://doi.org/10.1016/s0272-2712(01)00002-6

Carrubba, A., \& Calabrese, I. (1998). Antioxidant compound in some herbaceous aromatic plants. Acta Horticulturae, $\quad 457, \quad 85-93$. https://doi.org/10.17660/ActaHortic.1998.457.10

Chen, X., Li S., \& Liu, L. (2014). Engineering redox balance through cofactor systems. Trends Biotechnology, 32: 337-343. https://doi.org/10.1016/j.tibtech.2014.04.003

Chen, X., Zhang, L., Lie, J., Goa, F., \& Zhou, G. (2017). Hydrogen peroxide-induced change in meat quality of the breast muscle of broilers is mediated by ROS generation, apoptosis, and autophagy in the NF- $\kappa \mathrm{B}$ signal pathway. Journal of Agricultural and Food Chemistry, 65, 3986-3994. https://doi.org/10.1021/acs.jafc.7b01267

Corsello T., Komaravelli N., \& Casola A. (2018). Role of Hydrogen Sulfide in NRF2- and Sirtuin-Dependent Maintenance of Cellular Redox Balance. Antioxidants, $7,10$. https://doi.org/10.3390/antiox7100129

Das, U. N. (2002). A radical approach to cancer. Medical Science Monitor, 8, RA79-82.

Diplock, A. T. (1994). Antioxidant and Free Radical Scavengers. 113-130. In:, Rice-Evans, C.A. \& Burdon, R.H. (Eds.). Free Radical Damage and Its Control. Amsterdam: Elsevier, 389pp.

Halliwell, B., \& Gutteridge, J. M. C. (1989). Free Radicals, Ageing and Disease. 416-508. In: Halliwell, B., \& Gutteridge, J. M. C. (Eds.). Free Radicals, Biology and Medicine. Clarendon: Press. Oxford.

Harborne, J. B. (1984). Phytochemical methods: A guide to modern techniques of plant analysis, Chapman and Hall, London, New York. 288pp. https://doi.org/10.1007/978-94-009-5570-7 


\section{Al-Mosawy \& Al-Salhie / Basrah J. Agric. Sci., 34(1): 171-179, 2021}

Jirovetz, L., Buchbauer, G., Shafi, M. P., \& Leela, N. K. (2003). Analysis of the essential oils of the leaves, stems, rhizomes and roots of the medicinal plant Alpinia galanga from southern India. Acta Pharmaceutica, 53, 73-81. https://pubmed.ncbi.nlm.nih.gov/14764241/

Khastar, H. (2015). Protective effects of vitamin E against liver damage caused by renal ischemia reperfusion. Renal Failure, 37, 494-496. https://doi.org/10.3109/0886022X.2015.1006084

Mansouri, E., Khorsandi, L., \& Abedi, H.A. (2014). Antioxidant effects of proanthocyanidin from grape seed on hepatic tissue injury in diabetic rats. Iranian Journal of Basic Medical Sciences, 17, 460-464. https://doi.org/10.22038/ijbms.2014.2932

Mahae, N., \& Chaiseri, S. (2009). Antioxidant activities and antioxidative components in extracts of Alpinia galanga (L.) Sw. The Kasetsart Journal (Natural Science), 43,358 -369.

Negm, S. H., \& Ragheb, E. M. (2019). Effect of (Alpinia officinarum) hance on sex hormones and certain biochemical parameters of adult male experimental rats. Journal of Food and Dairy Sciences, 10, 315322. https://doi.org/10.21608/jfds.2019.55653

N.R.C. (1994). National Research Council. Nutrient Requirements of Poultry. $9^{\text {th }}$ edition. National Academic Science Washington, D.C, 176pp.

Sanja, J. P., Ljiljana, M. K., Nikola, M. P., Jovanka, D. L., Olivera, M. Đ., Bojana, M. K., Ivana, S. C.., \& Marina V. V. (2015). Effect of synbiotic on growth and antioxidant status of blood in broiler chicken. Food and Feed Research, 42, 163-169.

Schrader, M., \& Fahimi, H. D. (2006). Peroxisomes and oxidative stress. Biochimica et Biophysica Acta, 1763, 1755-1766. https://doi.org/10.1016/j.bbamcr.2006.09.006

SPSS (2016). Statistical Packages of Social Sciences. IBM Corp. Released 2016. IBM SPSS Statistics for Windows, Version 24.0. Armonk, NY: IBM Corp. https:// www. ibm. com/ analytics/spss-statisticssoftware
Sultan, A. T. M., Al-Salhie, K. C. K., \& Shawket, T. F. (2019). Effect of adding Lycium barbarum L. extract to drinking water on some productive traits of Japanese quail (Coturnix japonica) . Basrah Journal of Agricultural Sciences, 32, 208-212. https://doi.org/10.37077/25200860.2019.210

Sultan, A. T. M., Shawket, T. F., \& Al-Salhie, K. C. K. (2020). Effect of adding Lycium barbarum extract to drinking water on some physiological characteristics of Japanese quail (Coturnix japonica). AIP Conference Proceedings 2235, 5pp. https://doi.org/10.1063/5.0007488

Surai, P. F., \& Fisinin, V. I. (2016a). Vitagenes in poultry production. Part 1. Technological and environmental stresses. Worlds Poultry Science, Journal, 72:721733. https://doi.org/10.1017/S0043933916000714

Surai, P. F., \& Fisinin, V. I. (2016b). Vitagenes in poultry production. Part 2. Nutritional and internal stresses. Worlds Poultry Science, Journal, 72:761772. https://doi.org/10.1017/S0043933916000726

Van Beek, J. H., de Moor, M. H., de Geus, E. J., Lubke, G. H., Vink, J. M., Willemsen, G., \& Boomsma, D. I. (2013). The genetic architecture of liver enzyme levels: GGT, ALT and AST. Behavioural Genetic, 43, 329-339. https://doi.org/10.1007/s10519-0139593-y

Wu, T., Rifai, N., Roberts, L. J., Willett, W. C., \& Rimm, E. B. (2004). Stability of Measurements of Biomarkers of Oxidative Stress in Blood Over 36 Hours. Cancer Epidemiology, Biomarkers and Prevention, 13, 1399-1402.

Yagi, K. (1998). Simple assay for the level of total lipid peroxides in serum or plasma. Free Radical and Antioxidant Protocols, 108, 101-106. https://doi.org/10.1385/0-89603-472-0:101

Yang, X., \& Eilerman, R. G. (1999). Pungent principle of Alpinia galanga (L.) Swartz and its application. Journal of Agricultural and Food Chemistry, 47, 1657-1662. https://doi.org/10.1021/jf980822 
تأثير اضافة المستخلص الكحولي لجذور الخولنجان الكبير (Alpinia galanga L) في انزيمات مصل الدم

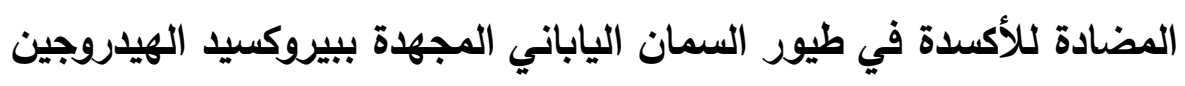

\author{
اسرار مكي صادق الموسوي و خالا جلاب كرياي الصالحي \\ قسم الانتاج الحيواني، كلية الزراعة، جامعة البصرة، العراق
}

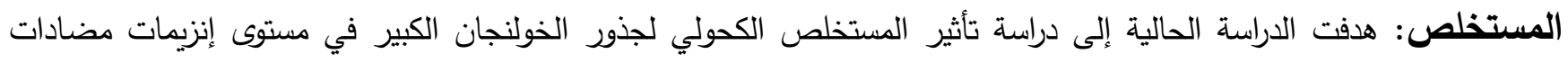

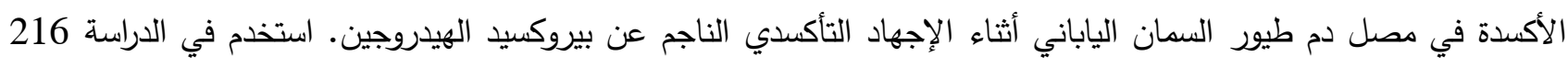

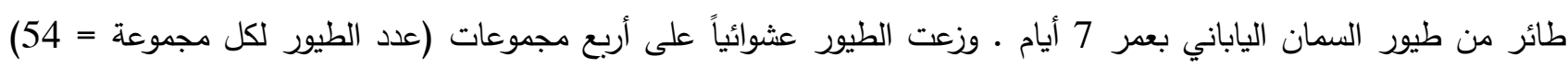

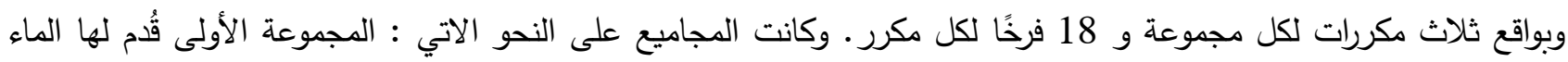

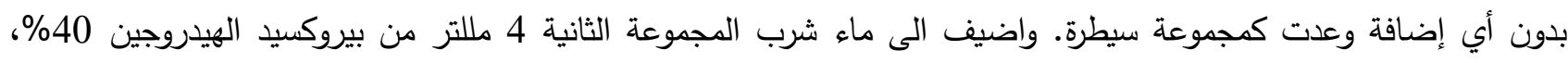

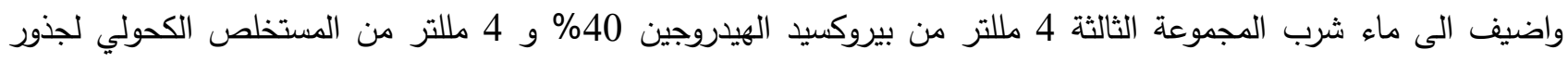

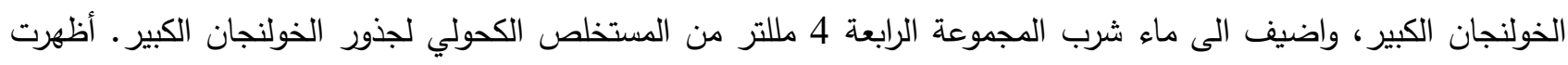

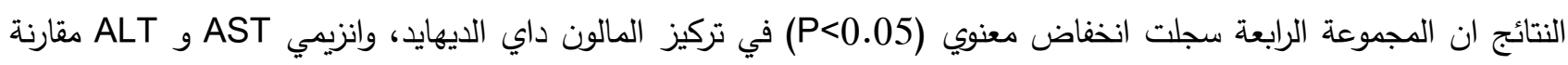

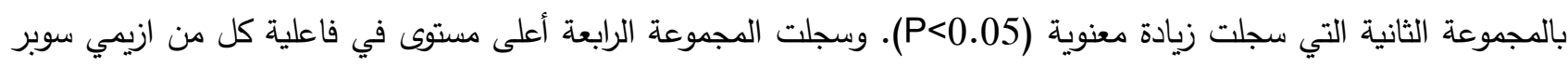

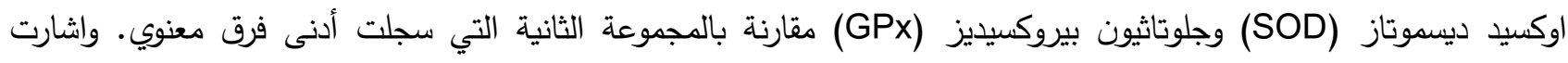

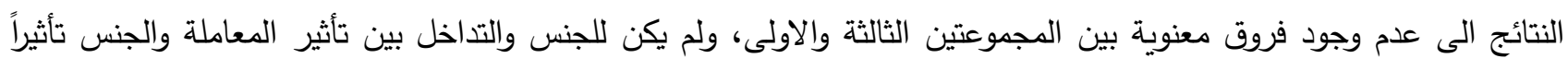

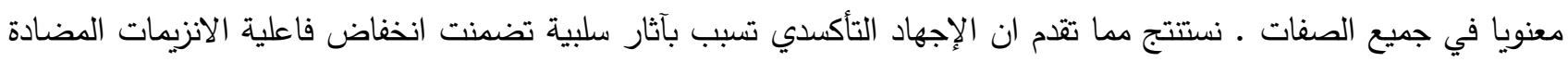

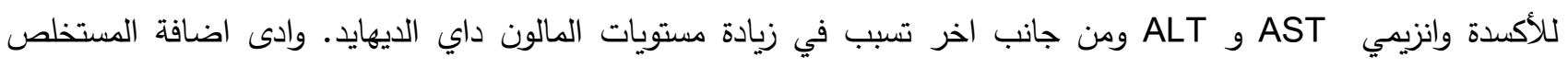
الكحولي لجذور الذولنجان الكبير الى الدد من تأثيرات بيروكسيد الهيدروجين السلبية. الكلمات المفتاحية: الخولنجان الكبير، الاجهاد التأكسدي، الانزيمات المضادة للأكسدة، السمان. 